\title{
Differential Human Multiple Myeloma Cell Line Responsiveness to Interferon- $\alpha$ Analysis of Transcription Factor Activation and Interleukin 6 Receptor Expression
}

\author{
Diane F. Jelinek, Kjersti M. Aagaard-Tillery, Bonnie K. Arendt, Taruna Arora, Renee C. Tschumper, and Jennifer J. Westendorf \\ Department of Immunology, Mayo Clinic/Foundation, Rochester, Minnesota 55905
}

\begin{abstract}
Although IFN- $\alpha$ is commonly used as maintenance treatment for multiple myeloma patients, its effectiveness is varied. In this study, we have used a panel of IL-6 responsive myeloma cell lines that vary remarkably in responsiveness to IFN- $\alpha$. Three cell lines were growth arrested by IFN- $\alpha$; however, IFN- $\alpha$ significantly stimulated growth of the fourth cell line, KAS-6/1. Our studies have focused on elucidating the mechanism of differential IFN- $\alpha$ responsiveness. First, we have shown that IFN- $\alpha$-stimulated growth of the KAS-6/1 cells did not result from induction of autocrine IL-6 expression. Second, analysis of Stats 1, 2, and 3 and IFN regulatory factor-1 (IRF-1) and IRF-2 activation failed to reveal differences between the IFN- $\alpha$ growth-arrested or growth-stimulated cells. Third, although IFN- $\alpha$ treatment of the IFN- $\alpha$ growth-inhibited cell lines reduced IL-6 receptor (IL-6R) expression, IFN- $\alpha$ also reduced KAS-6/1 IL-6R expression. Finally, although IFN- $\alpha$ treatment reduced IL-6R numbers on each cell line, analysis of Stat protein activation revealed that the receptors were still functional. We conclude that myeloma cell responsiveness to IFN- $\alpha$ is heterogeneous and that mechanisms of IFN- $\alpha$-mediated growth inhibition other than IL-6R downregulation must exist in myeloma. Identification of these mechanisms may allow development of agents that are more universally effective than IFN- $\alpha$. (J. Clin. Invest. 1997. 99:447-456.) Key words: autocrine IL-6 • growth factor $\bullet$ IFN- $\alpha \cdot$ cell cycle $\bullet$ myeloma
\end{abstract}

\section{Introduction}

The antiviral and antiproliferative effects of interferons on both normal and transformed cells have long been appreciated (for reviews see references 1 and 2). The typically growthinhibitory action of interferon has made it a commonly used therapeutic agent in the treatment of a wide variety of human malignancies (for reviews see references 2 and 3). Multiple myeloma $(\mathrm{MM})^{1}$ is a progressive and fatal disease characterized by the expansion of malignant plasma cells in the bone

Address correspondence to Diane F. Jelinek, Ph.D., Department of Immunology, Mayo Clinic, Rochester, MN 55905. Phone: 507-2845617; FAX: 507-284-1637; E-mail: jelinek.diane@mayo.edu

Received for publication 19 July 1996 and accepted in revised form 22 November 1996.

1. Abbreviations used in this paper: EMSA, electrophoretic mobility shift assay; IL-6R, IL-6 receptor; IRF, IFN regulatory factor; ISRE, IFN-stimulated response element; MM, multiple myeloma; $\mathrm{pY}$, antiphosphotyrosine antibody.

The Journal of Clinical Investigation

Volume 99, Number 3, February 1997, 447-456 marrow and by the presence of osteolytic lesions. Since the initial report of the promising effects of IFN- $\alpha$ as an effective therapy in MM (4), there has been a considerable number of clinical trials that have addressed the overall effectiveness of IFN- $\alpha$ (for reviews see references 5-7). Despite the relatively extensive clinical use of IFN- $\alpha$ in treatment of myeloma, there are reports suggesting that IFN- $\alpha$ may actually aggravate disease in vivo. Two groups have published case reports in which IFN- $\alpha$ therapy in MM patients resulted in the development of aggressive plasma cell leukemia $(8,9)$. Furthermore, some in vitro studies on either fresh patient cells or with established myeloma cell lines have shown that IFN- $\alpha$ may be modestly growth stimulatory for myeloma cells (10-12).

Although there is evidence that IFN- $\alpha$ may be growth stimulatory for some myeloma cells, there is also evidence that IFN- $\alpha$ inhibits myeloma cell growth (13-16). In addition, it has been suggested that it may do so by interfering with receptor expression for IL-6 $(15,16)$, a cytokine that has been identified as a primary growth factor for myeloma cells (17). Of interest, IFN- $\gamma$ has likewise been reported to inhibit myeloma cell growth in vitro $(18,19)$, and a similar mechanism of IL-6 receptor (IL-6R) downregulation has been proposed (19). However, it is important to point out that although IL-6R levels were clearly decreased in each of these studies, no attempt was made to determine whether the reduction in cytokine receptor number had functional consequences.

IFN- $\alpha$ and IL- 6 clearly use distinct receptor complexes, however, both cytokines have been shown to use a direct signal transduction pathway to the nucleus that involves activation of the Stat family of transcription factors (for reviews see references 20 and 21). The similarities between IL-6 and IFN- $\alpha$ also extend to gene regulation via the transcriptional activator IFN-regulatory factor-1 (IRF-1) and its antagonistic repressor IRF-2 (22, 23; for review see reference 24). Although members of the Stat and IRF families are known to play an important role in the signaling of growth, growth arrest, and differentiation (25-29), the potential role of these factors in accounting for the differential responsiveness of myeloma cells to IFN- $\alpha$ has not been addressed previously. In this study, therefore, we have analyzed IL-6R expression and IL-6- and IFN- $\alpha-$ stimulated transcription factor activation in a panel of IL-6-responsive human myeloma cell lines $(30,31)$ that display remarkable heterogeneity in IFN- $\alpha$ responsiveness. Because this panel encompasses the heterogeneity that has been reported in the literature, we were uniquely poised to examine the mechanism(s) accounting for the differential response of myeloma cells to IFN- $\alpha$.

\section{Methods}

Cell lines, culture medium, and reagents. The myeloma cell lines ANBL-6 (30), DP-6, KAS-6/1, and KP-6 (31) were derived in our laboratory. The ANBM-6 cell line is clonally identical to the ANBL-6 cell line (30). As described previously, these two cell lines were derived from 
the same patient and differ only in that the ANBL-6 line was established from peripheral blood and the ANBM-6 line was established from a bone marrow aspirate. Each cell line was maintained as described previously $(30,31)$. Recombinant IL-6 was generously provided by the Immunex Corp. (Seattle, WA). Recombinant purified human IFN- $\alpha-2 b$ was used at the indicated concentrations and was purchased from Schering Corp. (Kenilworth, NJ). IFN- $\gamma$ was purchased from Biosource International (Camarillo, CA). The IgG1 mAbs with neutralizing activities to IL-6 (Biosource), IL-6R (gp80; Biosource), and IL-1 $\beta$ (Biosource), as well as the isotype-matched control mAb (MOPC-21; Sigma Chemical Co., St. Louis, MO) were used at final concentrations of $300 \mathrm{ng} / \mathrm{ml}$. Rabbit polyclonal antibodies to Stat 1, Stat 3, p48, IRF-1, and IRF-2 were purchased from Santa Cruz Biotechnology, Inc. (Santa Cruz, CA) and rabbit anti-Stat 2 antibody was the generous gift of Dr. Chris Schindler (Columbia University, New York). The monoclonal anti-phosphotyrosine (pY) antibody was purchased from Upstate Biotechnology, Inc. (Lake Placid, NY).

Proliferation assays. The myeloma cells were washed three times to remove IL-6 present in culture media and resuspended in media lacking cytokines before culturing cells in 96-well round-bottom microtiter plates (Costar, Cambridge, MA) at a density of $2.5 \times 10^{4}$ cells/well and in a final volume of $200 \mu \mathrm{l}$. Cultures were conducted in triplicate in the presence of the indicated additions for $3 \mathrm{~d}$ at $37^{\circ} \mathrm{C}$ in the presence of $5 \% \mathrm{CO}_{2}$. DNA synthesis was quantitated using previously described methodology $(30,31)$.

Cytokine induction and preparation of nuclear extracts. Before assaying cytokine-mediated signaling, viable myeloma cells were first isolated with sodium diatrizoate/Ficoll gradients (Isolymph; GallardSchlesinger, Carle Place, NY), washed with saline, and recultured without IL-6 for $24-48 \mathrm{~h}$ in medium containing $1 \%$ FCS. In some experiments, cells were primed by overnight incubation with $1,000 \mathrm{U} / \mathrm{ml}$ IFN- $\gamma$. Immediately before cytokine stimulation, cells were washed and recultured in serum-free medium at a density of $5 \times 10^{6} \mathrm{cells} / \mathrm{ml}$. IL- 6 or IFN- $\alpha$ was added at a final concentration of $30 \mathrm{ng} / \mathrm{ml}$. Stimulation with cytokine(s) was terminated by addition of ice-cold PBS and immediate centrifugation. To prepare nuclear extracts, cells were quickly resuspended in $5 \mathrm{ml} 10 \mathrm{mM}$ Tris-Cl (pH 7.4), $10 \mathrm{mM} \mathrm{NaCl}$, and $6 \mathrm{mM} \mathrm{MgCl}_{2}$, and incubated on ice for $5 \mathrm{~min}$. After centrifugation, cells were resuspended in $800 \mu$ of the same buffer containing 1 mM DTT, $0.4 \mathrm{mM}$ PMSF, and $1 \mathrm{mM}$ sodium orthovanadate. Cells were then Dounce homogenized (30 strokes on ice), and nuclei were isolated by centrifugation for $3 \mathrm{~min}$ at $6,000 \mathrm{~g}$. Nuclear proteins were extracted for 20-30 min in 20-30 $\mu$ l of extraction buffer [ $20 \%$ glycerol, $20 \mathrm{mM}$ Hepes (pH 7.9), $420 \mathrm{mM} \mathrm{NaCl}, 1.5 \mathrm{mM} \mathrm{MgCl}_{2}, 0.2 \mathrm{mM}$ EDTA (pH 8.0), 0.2 mM PMSF, 1 mM DTT, $100 \mu \mathrm{M} \mathrm{Na}_{3} \mathrm{VO}_{4}, 3 \mu \mathrm{g} /$ $\mathrm{ml}$ aprotinin, $2 \mu \mathrm{g} / \mathrm{ml}$ pepstatin, and $1 \mu \mathrm{g} / \mathrm{ml}$ leupeptin] and cleared of insoluble material by centrifugation for $10 \mathrm{~min}$ at $12,000 \mathrm{~g}$. The protein concentration of the extracts was determined using a protein assay kit from Bio-Rad (Hercules, CA). Identical amounts of protein were used within experiments.

Electrophoretic mobility shift assay (EMSA). Nuclear extracts (2-5 $\mu \mathrm{g}$ of protein) were incubated with $0.5-1 \mathrm{ng}$ radiolabeled $\left({ }^{32} \mathrm{P}\right)$ doublestranded oligonucleotide probe $\left(\sim 5-7 \times 10^{4} \mathrm{cpm}\right.$ per reaction $)$ in binding buffer that contained $40 \mathrm{mM} \mathrm{KCl}, 1 \mathrm{mM} \mathrm{MgCl} 2,0.1 \mathrm{mM}$ EGTA, $0.5 \mathrm{mM}$ DTT, $20 \mathrm{mM}$ Hepes (pH 7.9), 4\% Ficoll (Ficoll400,000; Sigma Chemical Co.), $1 \mathrm{mg} / \mathrm{ml}$ BSA (GIBCO-BRL, Gaithersburg, MD), and $1 \mu \mathrm{g}$ poly dI-dC (Boehringer-Mannheim, Indianapolis, IN) at room temperature for $20 \mathrm{~min}$. The probes used in these studies have been described previously and include the serum inducible element of the c-fos promoter designated as SIE m67 (32); a trimer of the AAGTGA motif found in the positive regulatory domain I of the IFN- $\beta$ gene promoter designated as $\mathrm{C} 13(22,23)$; and the endogenous IFN-stimulated response element (ISRE) in the promoter of the 9-27 gene designated as 9-27 ISRE $(33,34)$. In those experiments in which antibodies were used to identify the shifted bands, extracts were preincubated on ice for $30 \mathrm{~min}$ with $1 \mu \mathrm{g}$ of antibody before addition of probe. For specificity determinations, extracts were incubated with cold competitive oligonucleotides during a preincubation period. Samples were electrophoresed through $4.5 \%$ polyacrylamide gels in $0.25 \times$ TBE ( $22 \mathrm{mM}$ Tris base, $22 \mathrm{mM}$ borate, 0.625 $\mathrm{mM}$ EDTA) at $450 \mathrm{~V}$ for $2 \mathrm{~h}$ at $4^{\circ} \mathrm{C}$. Gels were dried under vacuum, and radiolabeled species were detected by autoradiography at $-70^{\circ} \mathrm{C}$.

Immunoprecipitation and immunoblotting assays. For assay of Stat 2 and Stat 3 tyrosine phosphorylation, IL-6-deprived cells were stimulated as described above. Cells $\left(0.5-1 \times 10^{7}\right)$ were lysed in cold lysis buffer [0.5\% NP-40, $50 \mathrm{mM}$ Tris-Cl ( $\mathrm{pH} 8.0$ ), $10 \%$ glycerol, $0.1 \mathrm{mM}$ EDTA, $200 \mathrm{mM} \mathrm{NaCl}, 1 \mathrm{mM} \mathrm{Na}_{3} \mathrm{VO}_{4}, 0.1 \mathrm{mM}$ DTT, and protease inhibitors] and lysates were cleared of insoluble material by centrifugation for $10 \mathrm{~min}$ at $12,000 \mathrm{~g}$. Extracts were then precleared by the addition of $3 \mu$ l preimmune rabbit sera and protein A-Sepharose (Pierce, Rockford, IL) and agitation in the cold for $60 \mathrm{~min}$. After centrifugation, supernatants were incubated with $3 \mu l$ of either Stat 2 or Stat 3 antibody and agitated for $60 \mathrm{~min}$ at $4^{\circ} \mathrm{C}$ before adding protein A-Sepharose and incubation with agitation overnight at $4^{\circ} \mathrm{C}$. Immunoprecipitates were then washed two times with lysis buffer and one time with cold PBS. The pellet was resuspended in 30-50 $\mu$ l of $1.3 \times$ SDS gel loading buffer, heated to $100^{\circ} \mathrm{C}$ for $5 \mathrm{~min}$, resolved by SDS-PAGE, and transferred to Immobilon-P membranes (Millipore Corp., Bedford, MA). The membranes were blocked with $25 \mathrm{mM}$ Tris- $\mathrm{Cl}$ (pH 7.2), $150 \mathrm{mM}$ $\mathrm{NaCl}$, and $0.2 \%$ (wt/vol) Tween 20 (TBST) supplemented with $2 \%$ BSA. The membranes were first probed with anti-pY $(100 \mathrm{ng} / \mathrm{ml})$. After stripping with $7 \mathrm{M}$ guanidine, renaturation, and blocking, they were probed with either anti-Stat 2 or anti-Stat 3 antibodies $(1 \mu \mathrm{g} /$ $\mathrm{ml})$. Immunoreactive proteins were detected using an enhanced chemiluminescence detection system (Amersham, Arlington Heights, IL) and autoradiography.

${ }^{125}$ I-Labeled IL-6 binding assays. ${ }^{125} \mathrm{I}-\mathrm{IL}-6$ was purchased from Amersham (specific activity $800-1,200 \mathrm{Ci} / \mathrm{mmol}$ ). Cells were cultured for $48 \mathrm{~h}$ in media alone or in the presence or absence of IL-6 $(2 \mathrm{ng} / \mathrm{ml})$ or IFN- $\alpha(1,000 \mathrm{U} / \mathrm{ml})$. Next, they were washed three times in icecold PBS and resuspended in binding media (RPMI 1640 containing $2.5 \%$ BSA, $0.05 \%$ sodium azide, and $0.2 \mathrm{M}$ Hepes, $\mathrm{pH} 7.2$ ). Saturation binding experiments were determined by incubating $1-3 \times 10^{6}$ cells in $200 \mu \mathrm{l}$ binding buffer with increasing concentrations of ${ }^{125}$ I-IL-6 and in either the presence or absence of a 500-fold molar excess of unlabeled IL-6. Initial experiments indicated that ${ }^{125}$ I-IL-6 equilibrium binding occurs after $2 \mathrm{~h}$ (data not shown). Therefore, all binding studies were allowed to proceed for $3 \mathrm{~h}$ at $4^{\circ} \mathrm{C}$. Cell-associated ${ }^{125} \mathrm{I}-\mathrm{IL}-6$ was separated from unbound ${ }^{125} \mathrm{I}-\mathrm{IL}-6$ by layering samples onto oil gradients [ 2 parts bis (2-ethylhexyl) pthalate: 3 parts dibutyl phthalate; Sigma Chemical Co.] and spinning in a microcentrifuge. The tips of the tubes were then cut and bound and free radiolabel was quantitated using a gamma counter. Data were analyzed using the RadLig software package, version 4 (Biosoft, Cambridge, United Kingdom).

\section{Results}

Myeloma cell lines are heterogeneous in responsiveness to IFN- $\alpha$. During the course of establishing various human myeloma cell lines, heterogeneity in cytokine responsiveness was noted (30, 31). Therefore, the first experiments performed in this study focused on the heterogeneity observed in IFN- $\alpha$ responsiveness. As may be seen in Table I, the level of DNA synthesis observed in the absence of cytokines was variable from cell line to cell line. However, DNA synthesis by all four cell lines was notably enhanced by the presence of IL-6. Of interest, when IFN- $\alpha$ was assessed for its ability to promote myeloma cell DNA synthesis, two distinct patterns of responsiveness were noted. Thus, IFN- $\alpha$ suppressed DNA synthesis by the ANBL-6, ANBM-6, DP-6, and KP-6 cells cultured in the absence of any additional cytokines, but stimulated DNA synthesis in the KAS-6/1 cells. The level of IFN- $\alpha$-mediated augmentation of KAS-6/1 DNA synthesis was significant as indicated 
Table I. Effects of IL-6 and IFN- $\alpha$ on DNA Synthesis in Myeloma Cell Lines

\begin{tabular}{|c|c|c|c|c|}
\hline \multirow[b]{2}{*}{ Experiment } & \multirow[b]{2}{*}{ Cell line } & \multicolumn{3}{|c|}{ Stimulus } \\
\hline & & Nil & IL-6 & IFN- $\alpha$ \\
\hline & & \multicolumn{3}{|c|}{$\left[{ }^{3} \mathrm{H}\right]$ Thymidine incorporation $\left(\mathrm{cpm} \times 10^{-3}\right)$} \\
\hline \multirow[t]{4}{*}{1} & ANBL-6 & $6.0 \pm 0.5$ & $63.7 \pm 1.1$ & $1.4 \pm 0.1$ \\
\hline & DP-6 & $16.8 \pm 0.2$ & $26.6 \pm 0.7$ & $7.2 \pm 0.1$ \\
\hline & KAS-6/1 & $7.2 \pm 0.3$ & $48.8 \pm 0.8$ & $34.5 \pm 0.4$ \\
\hline & KP-6 & $8.8 \pm 0.1$ & $120.6 \pm 2.1$ & $0.4 \pm 0.1$ \\
\hline \multirow[t]{4}{*}{2} & ANBM-6 & $0.7 \pm 0.1$ & $54.4 \pm 0.1$ & $0.4 \pm 0.1$ \\
\hline & DP-6 & $18.1 \pm 0.3$ & $41.4 \pm 0.6$ & $9.7 \pm 0.1$ \\
\hline & KAS-6/1 & $12.9 \pm 0.6$ & $104.0 \pm 3.1$ & $39.7 \pm 0.1$ \\
\hline & KP-6 & $52.8 \pm 1.9$ & $250.5 \pm 2.4$ & $27.0 \pm 0.4$ \\
\hline
\end{tabular}

The indicated cell lines were cultured in the presence or absence of $1 \mathrm{ng} / \mathrm{ml}$ IL-6 or $500 \mathrm{U} / \mathrm{ml}$ (Experiment 1) to 1,000 U/ml IFN- $\alpha$ (Experiment 2) for $3 \mathrm{~d}$ before assaying DNA synthesis. Values represent the mean cpm of triplicate samples \pm SEM.

by stimulation indices ranging from 3- to 18-fold over cells cultured in medium alone.

Concentration-dependent inhibition or augmentation of myeloma proliferative responses by $I F N-\alpha$. Because it has been shown previously that low concentrations of IFN- $\alpha$ may stimulate myeloma cell DNA synthesis whereas high concentrations of IFN- $\alpha$ may be without effect or inhibitory $(10,12)$, the next experiments tested the effects of a wide range of IFN- $\alpha$ concentrations on our panel of myeloma cell lines in both the presence and absence of IL-6. As can be seen in Table II, IL-6 augmented DNA synthesis in all of the cell lines. When varying concentrations of IFN- $\alpha$ were similarly tested for their ability to support DNA synthesis, the KAS-6/1 cells were again noted to be the only myeloma cell line that was positively stim- ulated by this cytokine, even when very low concentrations of IFN- $\alpha$ were added. By contrast, IFN- $\alpha$ inhibited basal DNA synthesis by three other myeloma cell lines cultured in media alone. IFN- $\alpha$ also inhibited the IL-6-dependent response in these three cell lines. IFN- $\alpha$-mediated inhibition of myeloma cell DNA synthesis did not result from induction of programmed cell death or loss of viability. Instead, cell cycle analysis indicated that IFN- $\alpha$ induced a G0/G1 cell cycle block in growth-inhibitable myeloma cells (results not shown). Finally, IFN- $\alpha$-mediated growth stimulation of myeloma cells has been suggested to be dependent on cell density (12). However, IFN- $\alpha$ inhibited growth of the ANBL-6, DP-6, and KP-6 cells even when cell density was dropped to $3 \times 10^{3}$ cells/well (results not shown). These results support the conclusion that there are two distinct patterns of IFN- $\alpha$ responsiveness in human myeloma cells.

IFN- $\alpha$ stimulation of KAS-6/1 DNA synthesis does not result from induction of autocrine IL-6 expression. It has been reported that IFN- $\alpha$-induced myeloma cell growth is the secondary consequence of induction of autocrine IL-6 secretion (12). To determine whether a similar mechanism accounted for the ability of IFN- $\alpha$ to stimulate the KAS-6/1 cells, neutralizing antibodies specific for IL- 6 or the gp80 component of the IL-6R were added to cell cultures. As shown in Table III, growth of the KAS-6/1 cells in response to exogenous IL-6 was completely blocked by the addition of either anti-IL- $6 \mathrm{mAb}$ alone or in combination with the anti-IL-6 R mAb. Control antibodies were without effect on cell proliferation (MOPC, anti-IL-1 $\beta)$. By contrast, IFN- $\alpha$ stimulation of KAS-6/1 cell growth was not inhibited by addition of either the anti-IL- $6 \mathrm{mAb}$ alone or in the presence of an anti-IL-6R mAb. Additional experiments using a highly sensitive IL-6-specific ELISA also indicated that IFN- $\alpha$ did not stimulate IL- 6 expression by the KAS-6/1 cells (results not shown). These results suggest that IFN- $\alpha$-mediated growth stimulation of the KAS- $6 / 1$ cells does not involve induction of autocrine IL-6 expression.

Table II. Effects of IFN- $\alpha$ on IL-6-dependent and-independent Myeloma Cell Line DNA Synthesis

\begin{tabular}{|c|c|c|c|c|c|c|c|c|c|}
\hline \multirow[b]{2}{*}{ Experiment } & \multirow[b]{2}{*}{$\mathrm{U} / \mathrm{ml} \mathrm{IFN}-\alpha$} & \multicolumn{2}{|c|}{ ANBM-6 } & \multicolumn{2}{|c|}{ DP-6 } & \multicolumn{2}{|c|}{ KP-6 } & \multicolumn{2}{|c|}{ KAS-6/1 } \\
\hline & & Nil & IL-6 & Nil & IL-6 & Nil & IL-6 & Nil & IL-6 \\
\hline & & \multicolumn{8}{|c|}{$\left[{ }^{\beta} \mathrm{H}\right]$ Thymidine incorporation $\left(\mathrm{cpm} \times 10^{-3}\right)$} \\
\hline \multirow[t]{7}{*}{1} & 0 & $9.6 \pm 0.6$ & $128.1 \pm 1.8$ & $40.9 \pm 0.4$ & $49.2 \pm 0.6$ & $12.0 \pm 0.3$ & $129.1 \pm 3.0$ & $51.9 \pm 1.8$ & $116.1 \pm 0.3$ \\
\hline & 0.02 & $10.9 \pm 0.7$ & $90.4 \pm 1.1$ & $40.0 \pm 0.9$ & $39.6 \pm 0.3$ & $7.9 \pm 0.3$ & $104.1 \pm 6.3$ & $69.6 \pm 0.4$ & $107.2 \pm 1.6$ \\
\hline & 0.2 & $9.8 \pm 0.5$ & $78.0 \pm 0.6$ & $33.0 \pm 0.4$ & $30.4 \pm 1.2$ & $5.2 \pm 0.1$ & $73.8 \pm 2.4$ & $73.3 \pm 1.5$ & $107.6 \pm 2.0$ \\
\hline & 2 & $5.3 \pm 0.3$ & $59.5 \pm 1.1$ & $23.4 \pm 0.5$ & $24.4 \pm 0.4$ & $1.2 \pm 0.1$ & $31.7 \pm 0.8$ & $76.1 \pm 2.3$ & $103.1 \pm 1.5$ \\
\hline & 20 & $1.3 \pm 0.1$ & $24.5 \pm 0.8$ & $21.0 \pm 0.4$ & $19.4 \pm 0.6$ & $0.3 \pm 0.1$ & $4.4 \pm 0.2$ & $79.1 \pm 0.9$ & $98.2 \pm 1.2$ \\
\hline & 200 & $0.6 \pm 0.1$ & $4.4 \pm 0.1$ & $13.6 \pm 0.3$ & $14.1 \pm 0.3$ & $0.4 \pm 0.1$ & $1.2 \pm 0.1$ & $74.1 \pm 1.8$ & $81.3 \pm 0.4$ \\
\hline & 2000 & $0.5 \pm 0.1$ & $2.8 \pm 0.1$ & $7.2 \pm 0.2$ & $7.3 \pm 0.1$ & $0.3 \pm 0.1$ & $0.9 \pm 0.1$ & $71.1 \pm 1.3$ & $79.2 \pm 0.8$ \\
\hline \multirow[t]{8}{*}{2} & 0 & $6.6 \pm 0.2$ & $69.4 \pm 2.6$ & $20.0 \pm 0.4$ & $46.8 \pm 1.5$ & $24.5 \pm 0.4$ & $42.5 \pm 0.1$ & $29.8 \pm 1.4$ & $143.1 \pm 6.0$ \\
\hline & 0.002 & $7.0 \pm 0.4$ & $73.3 \pm 1.7$ & $22.8 \pm 0.4$ & $45.0 \pm 1.9$ & $26.8 \pm 0.4$ & $42.9 \pm 1.7$ & $32.1 \pm 0.8$ & $150.2 \pm 3.4$ \\
\hline & 0.02 & $5.9 \pm 0.3$ & $52.7 \pm 1.2$ & $23.5 \pm 0.1$ & $46.8 \pm 1.9$ & $26.4 \pm 0.6$ & $41.4 \pm 0.3$ & $37.6 \pm 1.8$ & $152.2 \pm 1.8$ \\
\hline & 0.2 & $7.2 \pm 0.1$ & $52.2 \pm 1.8$ & $27.1 \pm 1.0$ & $49.0 \pm 0.7$ & $27.3 \pm 0.8$ & $41.9 \pm 0.1$ & $40.5 \pm 3.8$ & $148.5 \pm 6.8$ \\
\hline & 2 & $6.8 \pm 0.4$ & $51.1 \pm 2.4$ & $30.9 \pm 0.8$ & $47.0 \pm 0.5$ & $25.3 \pm 0.9$ & $37.2 \pm 0.3$ & $53.4 \pm 3.2$ & $158.6 \pm 5.9$ \\
\hline & 20 & $3.6 \pm 0.3$ & ND & $33.8 \pm 0.4$ & $40.9 \pm 0.3$ & $19.9 \pm 0.5$ & $27.8 \pm 0.4$ & $76.1 \pm 2.6$ & $164.3 \pm 3.6$ \\
\hline & 200 & $0.9 \pm 0.1$ & $13.4 \pm 1.1$ & $22.7 \pm 0.8$ & $24.8 \pm 0.6$ & $10.6 \pm 0.6$ & $12.5 \pm 0.5$ & ND & ND \\
\hline & 2000 & $1.0 \pm 0.1$ & $3.4 \pm 0.2$ & $17.5 \pm 0.7$ & $16.4 \pm 0.7$ & $3.4 \pm 0.2$ & $3.7 \pm 0.2$ & $104.8 \pm 3.2$ & $140.5 \pm 1.8$ \\
\hline
\end{tabular}

The indicated cell lines were cultured in the presence or absence of $1 \mathrm{ng} / \mathrm{ml}$ IL- 6 and varying concentrations of IFN- $\alpha$ for $3 \mathrm{~d}$ before assaying DNA synthesis. Values represent the mean cpm of triplicate samples \pm SEM. $N D$, not done. 
Table III. Effects of Neutralizing IL-6 mAb on KAS-6/1 IFN- $\alpha$ Responsiveness

\begin{tabular}{|c|c|c|c|c|}
\hline \multirow[b]{2}{*}{ Experiment } & \multirow[b]{2}{*}{$\mathrm{mAb}$} & \multicolumn{3}{|c|}{ Stimulus } \\
\hline & & Nil & IL-6 & IFN- $\alpha$ \\
\hline & & $\left.{ }^{\beta} H\right]$ Thymi & incorporation & $\left.p m \times 10^{-3}\right)$ \\
\hline \multirow[t]{4}{*}{1} & Nil & $0.9 \pm 0.1$ & $30.2 \pm 0.4$ & $9.4 \pm 0.4$ \\
\hline & $\alpha$-IL-6, IL-6R & $0.8 \pm 0.1$ & $1.2 \pm 0.1$ & $9.8 \pm 0.3$ \\
\hline & MOPC & $1.5 \pm 0.1$ & $34.4 \pm 0.9$ & $10.6 \pm 0.1$ \\
\hline & $\alpha-\mathrm{IL}-1 \beta$ & $1.0 \pm 0.1$ & $30.6 \pm 0.3$ & $9.7 \pm 0.2$ \\
\hline \multirow[t]{2}{*}{2} & Nil & $13.7 \pm 0.9$ & $72.9 \pm 0.5$ & $45.3 \pm 1.3$ \\
\hline & $\alpha$-IL-6 & $17.0 \pm 1.0$ & $22.1 \pm 0.5$ & $44.5 \pm 1.2$ \\
\hline
\end{tabular}

KAS-6/1 cells were cultured in the presence or absence of $1 \mathrm{ng} / \mathrm{ml} \mathrm{IL-6}$

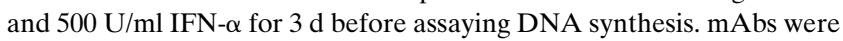
added at culture initiation. Values represent the mean cpm of triplicate samples \pm SEM.

Induction of DNA binding complexes by IL-6 and IFN- $\alpha$. Both IL- 6 and IFN- $\alpha$ have been shown to use a direct signal transduction pathway to the nucleus that involves phosphorylation and activation of cytoplasmic Stat proteins (for reviews see references 20 and 21). In initial experiments, the ANBL-6 and the KAS-6/1 cells were stimulated for varying lengths of time before isolation of nuclear extracts and analysis by EMSA. It may be seen in Fig. $1 A$ that extracts obtained from unstimulated ANBL- 6 or KAS-6/1 cells failed to shift migration of the radiolabeled SIE probe, a high-affinity target se-
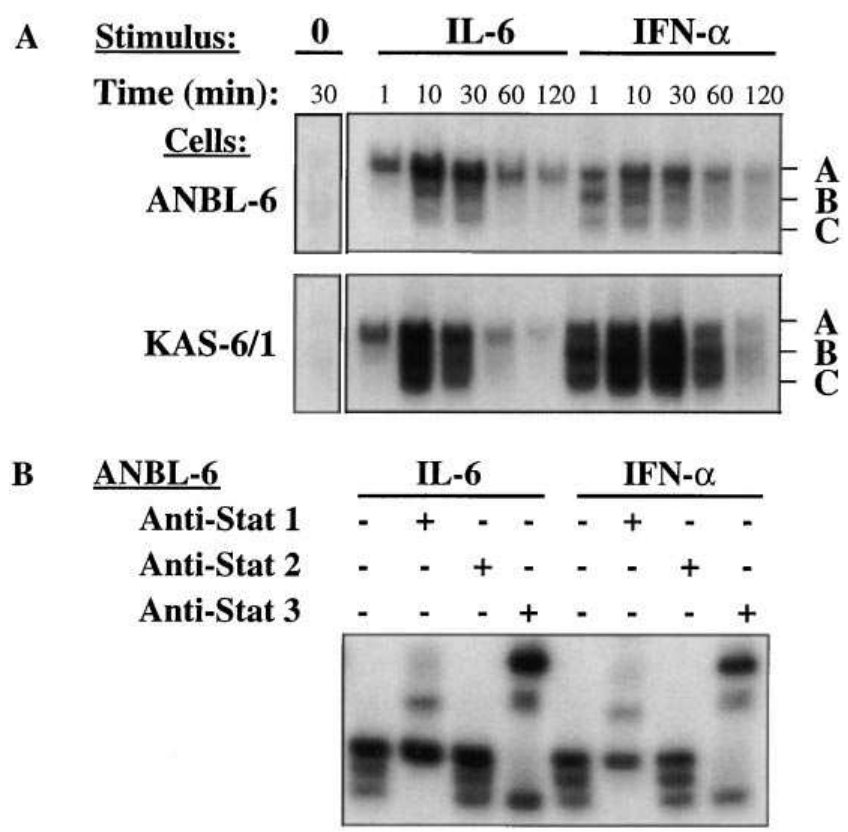

Figure 1. Cytokine-induced Stat factor activation. (A) IL-6-deprived ANBL- 6 and KAS-6/1 cells were stimulated with $30 \mathrm{ng} / \mathrm{ml} \mathrm{IL-6}$ or IFN- $\alpha$ for the indicated periods of time. Nuclear extracts were prepared, and DNA binding activities were measured by EMSA using a ${ }^{32} \mathrm{P}$-labeled SIE m67 oligonucleotide probe. (B) Nuclear extracts prepared from ANBL-6 cells after a 5-min stimulation with the indicated cytokines were incubated with $1 \mu \mathrm{g}$ of the indicated antibody before measuring SIE $\mathrm{m} 67$ binding activities by EMSA. quence for Stat factors activated in response to both IL-6 and IFN- $\alpha(32,35)$, thus indicating lack of presence of activated Stat factors in the nuclei of unstimulated myeloma cells. By contrast, addition of either IL- 6 or IFN- $\alpha$ resulted in the variable appearance of three distinct bands, designated A, B, and C. Results shown in Fig. $1 \mathrm{~B}$ using specific antibodies to Stat 1 , 2, and 3 suggest that complex A consists of Stat 3 homodimers, complex C consists of Stat 1 homodimers, and complex B consists of Stat $1 /$ Stat 3 heterodimers. Because the SIE probe is not useful for analysis of Stat 2 activation, addition of a Stat 2 antibody was without effect in this experiment and therefore serves as a negative control. Notable differences were observed between the kinetics of IL-6- and IFN- $\alpha$-stimulated cells. Thus, whereas IFN- $\alpha$ stimulation for as little as $1 \mathrm{~min}$ resulted in activation of both Stat 1 and Stat 3 in both cell lines, IL-6 stimulation for 1 min resulted primarily in the appearance of Stat 3. IL-6-stimulated activation of Stat 1 required a longer period of time. The delayed activation of Stat 1 upon IL-6 stimulation is consistent with results obtained by Zhang et al. (36). It is notable that there were no major discernible differences in induction of DNA-protein complexes between myeloma cells that are growth stimulated by IFN- $\alpha$ (KAS-6/1) or growth inhibited by IFN- $\alpha$ (ANBL-6). When excess cold SIE probe was added, the specific cold probe consistently inhibited the appearance of all three complexes in all experiments (data not shown).

Stat factor tyrosine phosphorylation in ANBL-6 and KAS$6 / 1$ cells. The next experiments were designed to determine whether differences in Stat 2 expression and/or activation might exist between the cell lines. To address this possibility,
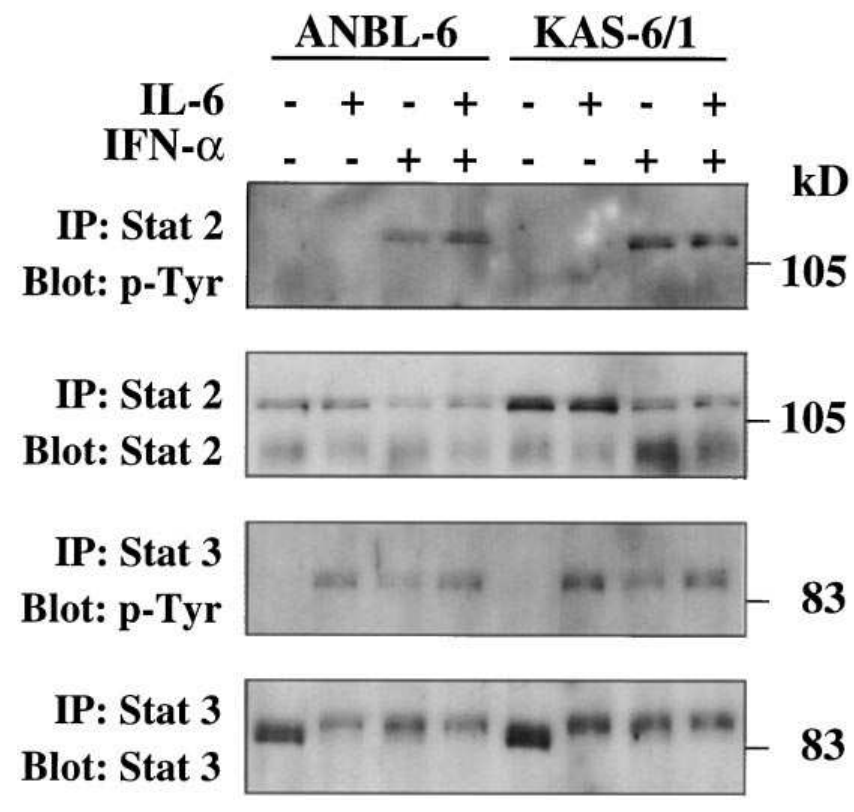

Figure 2. Cytokine-induced Stat 2 and Stat 3 phosphorylation. ANBL- 6 and KAS-6/1 cells were stimulated with the indicated cytokines for $15 \mathrm{~min}$ before preparation of total cellular lysates. Lysates were immunoprecipitated with Stat 2 antisera (top two panels) or with Stat 3 antisera (bottom two panels). Precipitated proteins were resolved by SDS-PAGE, transferred to Immobilon-P membranes, and immunoblotted sequentially with anti-pY (first and third panels) and anti-Stat 2 (second panel) or anti-Stat 3 (bottom panel) antibodies. 


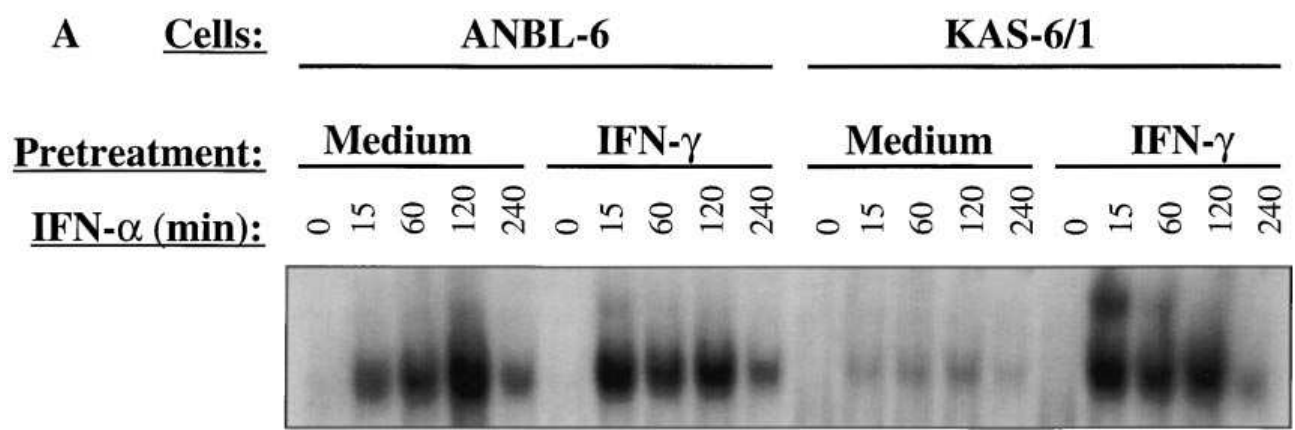

B

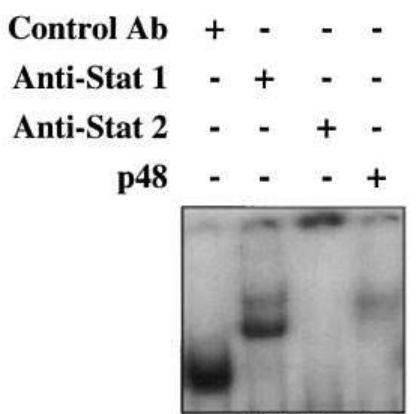

ANBL-6

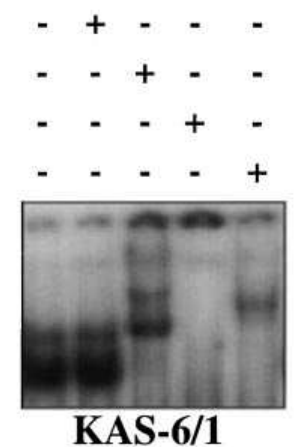

Figure 3. IFN- $\alpha$ stimulated induction of ISGF-3 activity. $(A)$ ANBL- 6 and KAS-6/1 cells were cultured overnight in the presence or absence of $1,000 \mathrm{U} / \mathrm{ml}$ IFN- $\gamma$, washed, and then stimulated with $30 \mathrm{ng} / \mathrm{ml}$ of IFN- $\alpha$ for the indicated periods of time before preparation of nuclear extracts. DNA binding activities were measured by EMSA using a ${ }^{32}$ P-labeled 9-27 ISRE oligonucleotide probe. $(B)$ Extracts obtained from IFN- $\alpha$-stimulated (15 $\mathrm{min}), \mathrm{IFN}-\boldsymbol{\gamma}$-primed ANBL- 6 and KAS-6/1 cells were further analyzed by incubation with $1 \mu \mathrm{g}$ of the indicated antibody before addition of the 9-27 ISRE probe.
Stat 2 activation was assessed by induction of tyrosine phosphorylation. As expected and as shown in Fig. 2 (top), tyrosine phosphorylation of Stat 2 only resulted after IFN- $\alpha$ stimulation. Importantly, there were no discernible differences in Stat 2 activation between the ANBL-6 and KAS-6/1 cells. Fig. 2 also displays the results obtained when Stat 3 was immunoprecipitated from each cell line and examined for tyrosine phosphorylation status. Consistent with the results shown above demonstrating that both cytokines stimulated the activation and nuclear translocation of Stat 3 into the nucleus, it may be seen in the third panel in Fig. 2 that both IL- 6 and IFN- $\alpha$ stimulated the tyrosine phosphorylation of Stat 3 in both cell lines.

$I F N-\alpha$ stimulated induction of ISGF-3 activity. IFN- $\alpha$ has been shown to result in the rapid transcriptional activation of a large number of genes (for review see reference 37). Many of these genes have yet to be characterized, however, several of these genes have been studied extensively and it has been shown that some of these require the ISGF-3 transcription factor complex (Stat 1, Stat 2, p48) for activation via ISRE binding sites (for review see reference 38). To determine whether IFN- $\alpha$ had differential effects on induction of ISGF-3 activation in the ANBL-6 and KAS-6/1 cells, we next performed mobility shift assays using a DNA fragment that contained the ISRE from a known IFN-inducible gene, 9-27 (33, 34). Moreover, because it has been shown that IFN- $\gamma$ pretreatment may prime cells for subsequent IFN- $\alpha$-stimulated ISGF-3 activation (34), we carried out similar studies. Results shown in Fig. $3 A$ demonstrate that IFN- $\alpha$ stimulation resulted in the rapid activation of 9-27 ISRE binding activity in both cell lines. Fig. $3 B$ demonstrates that this activity consists of Stat 1 , Stat 2 , and $\mathrm{p} 48$, the known constituents of ISGF-3. Although IFN- $\alpha$ stimulated ISGF-3 activation in both cell lines even without IFN- $\gamma$ pre- treatment, it is of some interest that IFN- $\gamma$ priming was effective in the KAS-6/1 cells, but not in the ANBL-6 cells.

Analysis of IRF-1 and IRF-2 binding activity. In addition to the Stat family of transcription factors, IFN- $\alpha$ also stimulates gene transcription via members of the IRF family of transcription factors. To determine whether IFN- $\alpha$ had differential effects on induction of IRF binding activity, we next assessed IRF-1 and IRF-2 activity by mobility shift assays. As may be seen in Fig. 4, both cell lines displayed strong constitutive binding of IRF-2 as revealed by supershift analysis. Of interest, IFN- $\alpha$ stimulated an apparent increase in IRF-2 binding activity in the ANBL- 6 cells but not in the KAS-6/1 cells. When IRF-1 binding activity was analyzed by supershift, there was no detectable IRF-1 binding in unstimulated ANBL-6 or KAS-6/1 cells. IFN- $\alpha$ stimulation did induce IRF-1 binding, however, in both cell lines it may be seen that the level of induction was extremely modest. These results, along with those presented in Figs. 1-3, suggest that growth stimulation or growth inhibition in response to IFN- $\alpha$ is not the result of differential activation of known members of the Stat or IRF family of transcription factors in the representative cell lines.

Effects of IFN- $\alpha$ on IL-6R expression. It has been suggested recently that IFN- $\alpha$ inhibited growth of the U266 human myeloma cell line by downregulating both chains of the IL-6R complex (15). To determine whether a similar mechanism was operative in the cell lines studied in this report, each of the four cell lines were cultured in media alone, or with IL-6, IFN- $\alpha$, or the combination of the two cytokines for $48 \mathrm{~h}$ before assaying for radiolabeled ${ }^{125}$ I-IL-6 binding. Fig. 5 depicts representative Scatchard analyses and accompanying saturation binding experiments for both the ANBL-6 and KAS-6/1 cell lines after culture under these four conditions. The inset graphs in 


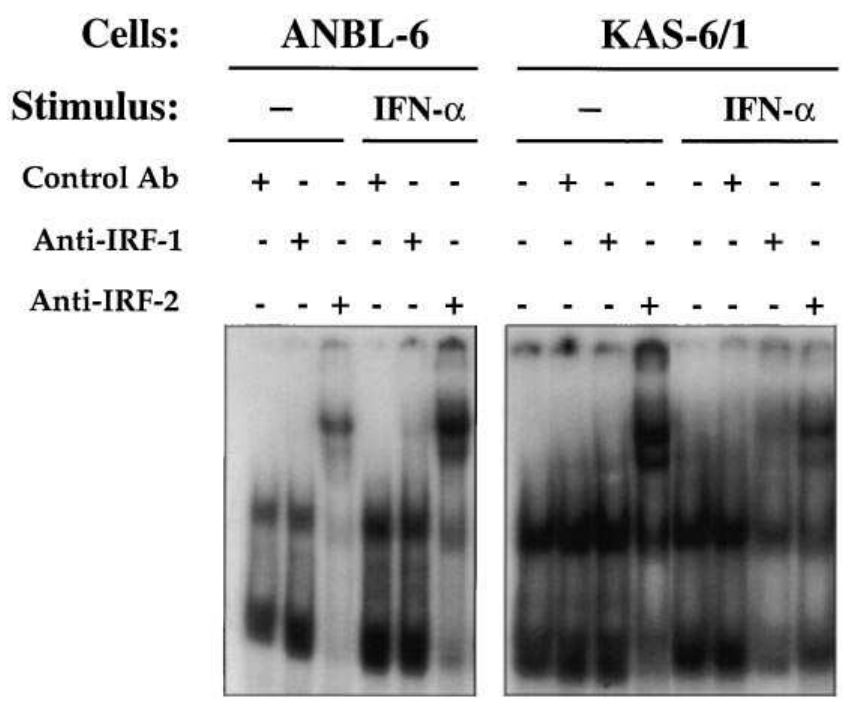

Figure 4. Analysis of IRF-1 and IRF-2 binding activity. IL-6-deprived ANBL- 6 and KAS-6/1 cells were incubated with or without $30 \mathrm{ng} / \mathrm{ml}$ IFN- $\alpha$ for $2 \mathrm{~h}$ before preparation of nuclear extracts. Nuclear extracts were incubated with $1 \mu \mathrm{g}$ of the indicated antibody before analysis of DNA binding activity by EMSA using a ${ }^{32} \mathrm{P}$-labeled trimeric $\mathrm{C} 13$ probe.

Fig. 5, $A$ and $B$, demonstrate that ${ }^{125}$ I-IL-6 binding on both cell lines was specific and saturable. Of interest, IFN- $\alpha$ treatment of both cell lines resulted in a significant reduction in ${ }^{125}$ I-IL-6 binding (closed circles). Because both of these cell lines are dependent on IL- 6 for long-term growth, to eliminate the possibility that cells starved of IL-6 would upregulate IL-6R number, we also analyzed ${ }^{125}$ I-IL- 6 binding to cells cultured in medium alone, or IL- 6 and IFN- $\alpha$. Although IL- 6 deprivation did not influence IL-6R expression on the ANBL-6 cells (Fig. 5 A, closed squares), it did augment IL-6R levels on the KAS$6 / 1$ cells over those observed on cells cultured in the presence of IL-6 (Fig. $5 \mathrm{~B}$ ). Regardless of these differences, IFN- $\alpha$ was observed to uniformly inhibit ${ }^{125}$ I-IL-6 binding in both cell lines. The results shown in Fig. 5 are summarized in Table IV along with results from similar analysis of ${ }^{125}$ I-IL-6 binding to both the DP- 6 and KP- 6 cell lines. Thus, it may be seen that although the $K_{\mathrm{d}}$ remained relatively constant after the various treatments in each of the four cell lines, the ${ }^{125}$ I-IL-6 binding sites/cell were markedly diminished by IFN- $\alpha$.

Stat factor activation in IFN- $\alpha$ pretreated myeloma cell lines. Although the results presented in Fig. 5 and Table IV suggested that IFN- $\alpha$ treatment decreased IL-6R expression in each cell line, the observation that similar treatment of the KAS-6/1 cells which are growth stimulated by IFN- $\alpha$ also resulted in decreased IL-6R expression suggested that this may not be the mechanism accounting for growth inhibition of myeloma cells. To determine if the IFN- $\alpha-$-mediated reduction in IL-6R expression resulted in subsequent insensitivity to IL-6, IFN- $\alpha$ pretreated cells were stimulated with increasing concentrations of IL-6 before isolation of nuclear extracts and analysis of Stat factor activation. Although IL-6R expression on all four cell lines was decreased by IFN- $\alpha$ (Table IV), it may be seen in Fig. 6 that each cell line expressed functional IL-6Rs as revealed by Stat factor activation. It is important to note that although higher concentrations of IL- 6 were required to result
Table IV. Effects of IL-6 and IFN- $\alpha$ on IL-6R Expression

\begin{tabular}{llcr}
\hline Cell line & Pretreatment & $K_{\mathrm{d}}\left(\times 10^{-10}\right)$ & Sites/cell \\
\hline \multirow{2}{*}{ ANBM-6 } & Medium & 3.6 & 9928 \\
& IL-6 & 4.0 & 10391 \\
& IFN- $\alpha$ & 3.8 & 5637 \\
DP-6 & IL-6 + IFN- $\alpha$ & 3.4 & 5350 \\
& Medium & 4.2 & 6733 \\
& IL-6 & 3.4 & 4882 \\
& IFN- $\alpha$ & 5.4 & 1577 \\
KAS-6/1 & IL-6 + IFN- $\alpha$ & 4.4 & 1500 \\
& Medium & 3.5 & 4344 \\
& IL-6 & 6.3 & 4165 \\
& IFN- $\alpha$ & 2.9 & 1210 \\
KP-6 & IL-6 + IFN- $\alpha$ & 3.2 & 844 \\
& Medium & 4.4 & 2204 \\
& IL-6 & 6.1 & 2060 \\
& IFN- $\alpha$ & 3.0 & 823 \\
& IL-6 + IFN- $\alpha$ & 1.9 & 357 \\
\end{tabular}

Cells were cultured in the presence or absence or $1 \mathrm{ng} / \mathrm{ml} \mathrm{IL-6}$ and/or $1,000 \mathrm{U} / \mathrm{ml} \mathrm{IFN}-\alpha$ for $48 \mathrm{~h}$ before analyzing cells for ${ }^{125}$ I-labeled IL-6 binding.

in maximal Stat factor activation in each of the treated cell lines, the data shown in Fig. 6 clearly indicate that the IL-6Rs, although fewer in number, are still capable of signal transduction. These results suggest that the ability of IFN- $\alpha$ to inhibit growth by the ANBL-6, ANBM-6, DP-6, and KP-6 cells does not occur as a consequence of IL-6R downregulation.

\section{Discussion}

IFN- $\alpha$ has been used as an antiproliferative agent for the treatment of a variety of human malignancies, including MM. However, conflicting reports are present in the literature regarding the sensitivity of myeloma cells to IFN- $\alpha$. In this study, we have analyzed a panel of IL- 6 responsive human myeloma cell lines for IFN- $\alpha$ responsiveness and add further support to previous observations in the literature that myeloma cells are heterogeneous with respect to IFN- $\alpha$ sensitivity. Moreover, this panel also provided a unique opportunity to analyze several mechanisms of differential IFN- $\alpha$ responsiveness by allowing comparative studies to be done between myeloma cells that were growth arrested or stimulated by IFN- $\alpha$. Our results suggest that the opposing patterns of responsiveness cannot be accounted for by induction or inhibition of autocrine growth factor loops, differential activation of Stat or IRF proteins, or downmodulation of IL-6Rs.

Multiple mechanisms have been suggested for the antiproliferative action of IFN- $\alpha$ (for reviews see references 1 and 2). One of these mechanisms is the induction of the enzyme $2^{\prime}, 5^{\prime}$ oligoadenylate synthetase (2,5-A synthetase) which ultimately stimulates the activity of latent ribonuclease $\mathrm{L}$, an enzyme that catalyzes mRNA and rRNA degradation (for review see reference 39). Therefore, ribonuclease activity has been speculated to result in degradation of mRNAs that may be crucial for proliferation. Indeed, it has been proposed that IFN- $\alpha$ disrupts an autocrine TNF- $\alpha$ growth loop in both hairy cell leukemia and 

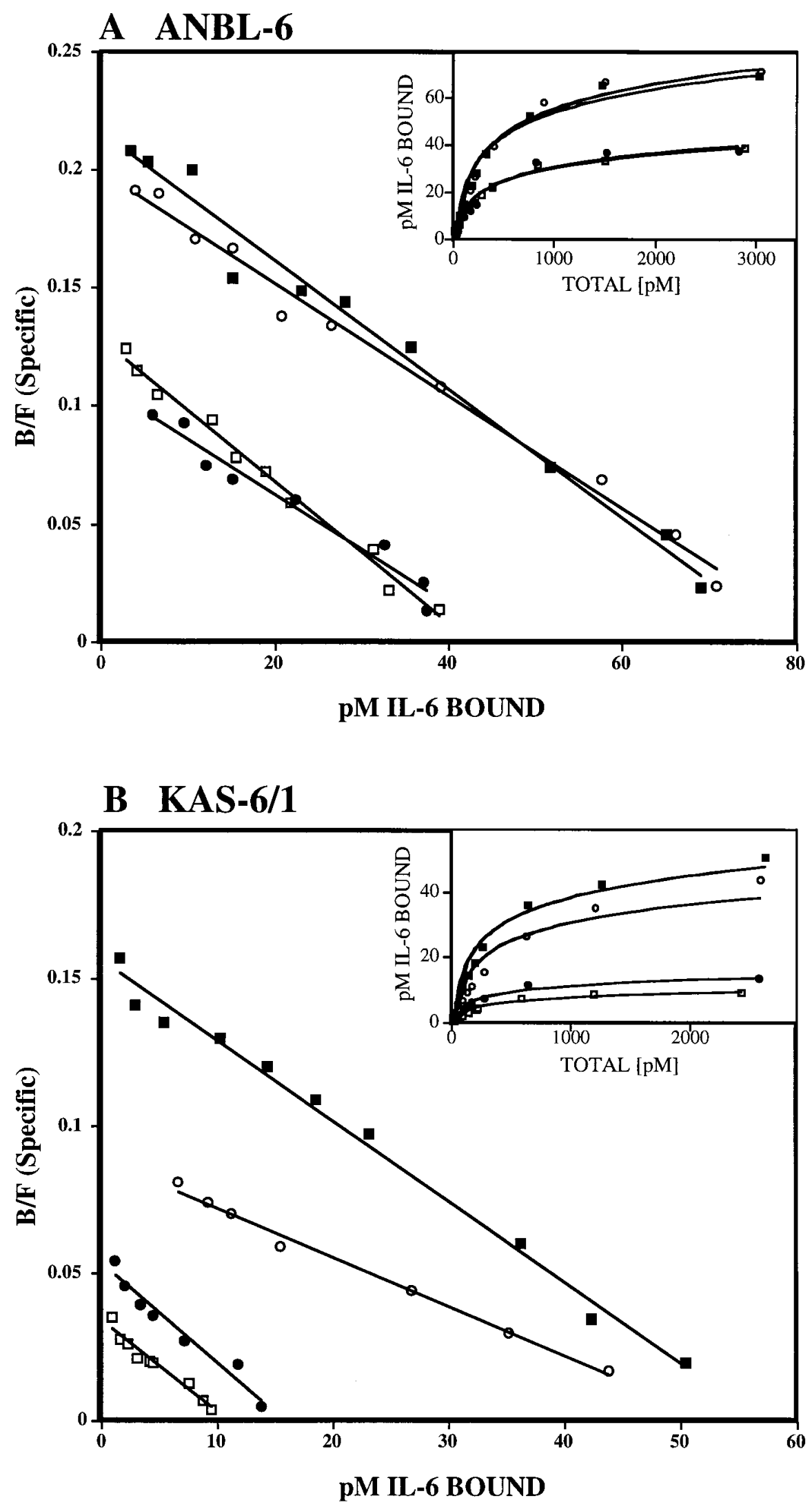

Figure 5. Analysis of IL-6R expression. ANBL-6 and KAS-6/1 cells were cultured for $48 \mathrm{~h}$ in media alone (closed squares), $1 \mathrm{ng} / \mathrm{ml}$ IL-6 (open circles), $1,000 \mathrm{U} / \mathrm{ml}$ IFN- $\alpha$ (closed circles), or the combination of IL- 6 and IFN- $\alpha$ (open squares) before extensively washing the cells and assaying for ${ }^{125}$ I-IL-6 binding.

B cell chronic lymphocytic leukemia. Thus, these investigators were able to correlate a rise in 2,5-A synthetase mRNA with a decrease in stability of TNF- $\alpha$ mRNA (40). Although we have not analyzed 2,5-A synthetase activation in our panel of my- eloma cell lines, our data do not support the hypothesis that growth inhibition results from inhibition of autocrine IL-6 production. First, the ANBL-6 cells were growth inhibited by IFN- $\alpha$ even though this cell line does not make autocrine IL-6 

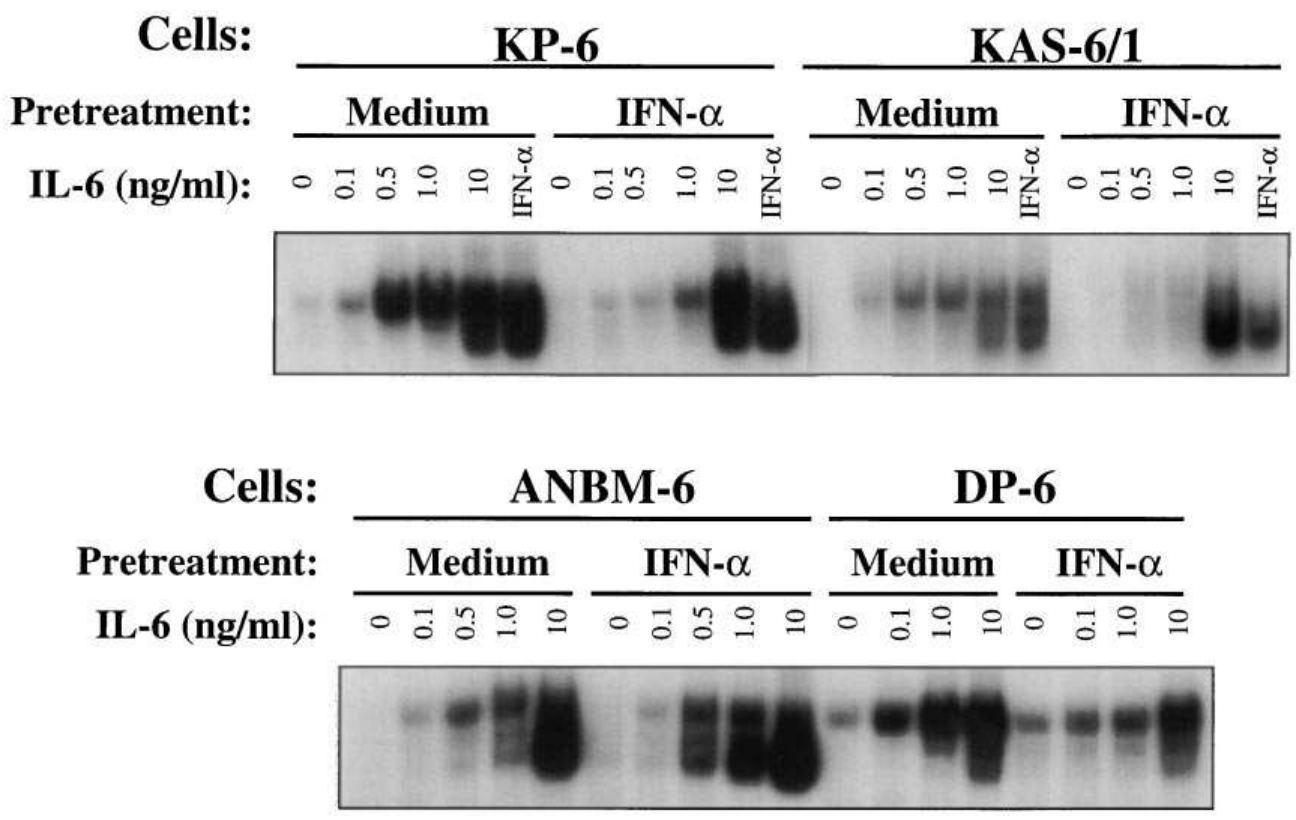

Figure 6. IL-6 induced Stat factor activation in IFN- $\alpha$-pretreated cells. Each of the four myeloma cell lines were cultured for $48 \mathrm{~h}$ in media alone or media containing $1,000 \mathrm{U} / \mathrm{ml}$ IFN- $\alpha$. Cells were then stimulated with increasing concentrations of IL-6 for $15 \mathrm{~min}$ before isolation of nuclear extracts and EMSA analysis of SIE m67 binding activities. The KP-6 and KAS-6/1 cells were also assessed for IFN- $\alpha$ stimulation of binding activities (top, lanes 6 , 12,18 , and 24). $5 \mu \mathrm{g}$ of nuclear extract was assayed for binding activity in each experimental point. unless stimulated via the CD40 cell surface molecule (41). Second, even though both the KP-6 and the DP-6 cells are capable of low levels of autocrine IL-6 expression, IFN- $\alpha$ was still growth inhibitory even in the presence of added IL-6. Although it remains possible that induction of latent ribonuclease activity results in degradation of other crucial growthregulatory mRNAs in the IFN- $\alpha$ growth-inhibitable cell lines, if this mechanism were operative, a corollary of this hypothesis would have to be that IFN- $\alpha$ does not induce ribonuclease activity in the KAS-6/1 cells. This possibility is being explored currently.

In this study, we tested the hypothesis that differential responsiveness to IFN- $\alpha$ resulted from differential activation of the Stat family of transcription factors. Stat 3 activation has been shown recently to play an essential role in IL-6-mediated induction of growth arrest and differentiation in the murine myeloid leukemic cell line, M1 $(26,27)$. Stat 3 has also been suggested to be crucial in IFN- $\alpha$ signal transduction. Thus, work by Yang et al. (28) demonstrated that Stat 3 was the only signaling molecule in the Jak/Stat pathway that was not activated by IFN- $\alpha$ in an IFN- $\alpha$-resistant Daudi B lymphoblastoid subline. Finally, using the mutant U3A cell line that lacks Stat 1 and is defective in response to IFN- $\alpha$ or IFN- $\gamma$, Chin et al. (29) provided evidence that Stat 1 was essential for growth suppression in response to IFN- $\gamma$ via its ability to induce expression of the cyclin-dependent kinase inhibitor, p21 ${ }^{\mathrm{WAF} 1 / \mathrm{CIP} 1 / \mathrm{CAP} 1}$. With respect to the experiments carried out in this study, however, we could not detect obvious differences in the patterns of Stat protein activation between cells that were growth inhibited by IFN- $\alpha$ versus those that were growth stimulated. Although our results differ from the findings that Stat 3 is important for IFN- $\alpha$ signaling (28), it is important to point out that those investigators were using a cell line that was resistant to the antiproliferative actions of IFN- $\alpha$. The KAS-6/1 cell line used in this study can not be classified as resistant, but rather as one which is sensitive to IFN- $\alpha$ although in an apparently atypical fashion, i.e., it is growth stimulated. Similarly, our results are inconsistent with the reports regarding the importance of Stat 1 in growth inhibition. EMSA analysis using the SIE probe clearly indicated that Stat 1 was activated by both IL- 6 and IFN- $\alpha$ in each cell line irrespective of growth outcome upon IFN- $\alpha$ stimulation.

To expand the scope of our studies, we also assessed the cell lines for potential differences in ISGF-3 activation by using a probe that contained the ISRE located within the IFNstimulated gene, 9-27. However, this analysis again revealed comparable ISGF-3 activation in either IFN- $\alpha$ growth-inhibitable or growth-stimulated cells. It is of some interest to point out that IFN- $\gamma$ priming greatly augmented ISGF-3 activation in the KAS-6/1 cells, but not in the ANBL-6 cells. Because IFN- $\gamma$ priming has been suggested previously to result in upregulation of the gamma component of ISGF-3, p48 (34), these results suggest that the ANBL- 6 and KAS-6/1 cell lines may differ with respect to constitutive levels of $\mathrm{p} 48$. The significance of this observation remains to be determined.

The IRF-1 and IRF-2 transcription factors have also been shown to be important mediators of both IL- $6-$ and IFN- $\alpha-$ induced gene transcription. Because increased levels of IRF-1 have been associated with growth arrest (42) and overexpression of IRF-2 can result in cell transformation and increased tumorigenicity (43), we assessed the expression and DNA binding activities of IRF-1 and IRF-2 in these studies as well. However, our studies failed to reveal significant differences between IRF-1 and IRF-2 expression and/or induction patterns in the ANBL- 6 and KAS-6/1 cells. IFN- $\alpha$ treatment was only modestly effective at inducing IRF-1 DNA-binding activity in either cell line. In preliminary studies, however, IFN- $\alpha$ does induce IRF-1 mRNA expression in both cell lines (Arora, T., and D.F. Jelinek, manuscript submitted for publication).

Although our results indicated that the pattern of Stat protein activation induced by IFN- $\alpha$ did not vary among our four cell lines, nor were there significant differences between induction of ISGF3 or IRF-1 and IRF-2 binding activities, it remains possible that the cell lines are capable of differentially expressing a gene(s) that becomes transcriptionally activated upon IFN- $\alpha$ stimulation and results in either downstream cell cycle 
arrest or progression. IFNs have long been known to result in the rapid transcriptional activation of a large number of genes $(37,44-46)$ as well as to rapidly downmodulate a number of genes, the expression of which often correlates with proliferation. It is highly likely that only a fraction of IFN-responsive genes have thus far been identified. Furthermore, the function of many of the products of genes that have been identified as being IFN-responsive has remained elusive. Klein and coworkers have reported that one such IFN-responsive gene in myeloma may be the IL-6 gene (12). However, we have not been able to demonstrate that IFN- $\alpha$ stimulation of the KAS$6 / 1$ cell line resulted from a similar mechanism. It remains possible that IFN- $\alpha$ stimulates IL- 6 transcription in the KAS-6/1 cells at a very low level. However, all of our efforts to date have failed to find evidence of IL- 6 protein in the IFN- $\alpha$-stimulated KAS-6/1 cells.

An equally plausible candidate for an IFN- $\alpha$ responsive gene that could explain growth inhibition in IL-6-responsive myeloma cells is that of the ligand binding chain of the IL-6R complex, gp80. Although two groups have suggested that IFN- $\alpha$ treatment of the IFN- $\alpha$ growth-inhibited U266 myeloma cell line results in downregulation of the IL-6R $(15,16)$, neither group of investigators assessed the functional consequences of IL-6R downregulation in the IFN- $\alpha$-treated cells. Anthes et al. (16) reported that a 48-h incubation with IFN- $\alpha$ reduced IL-6Rs to $<200$ receptors per cell and Schwabe et al. (15) reported that IFN- $\alpha$ abolished high-affinity IL-6R expression and decreased the number of low-affinity sites by $\sim 60 \%$. However, these investigators did not directly address how many IL-6Rs were required to trigger signal transduction. For example, it has been shown that as few as 10 ligated IL-1 receptors per cell are needed to elicit a biological response from T lymphocytes $(47,48)$.

Our work also demonstrated that IFN- $\alpha$ decreased IL-6R expression in human myeloma cell lines. However, our study can be distinguished from previous reports in the literature by simultaneous analysis of IFN- $\alpha$ growth-inhibited as well as growth-stimulated myeloma cells. Somewhat surprising, despite stimulating KAS-6/1 cell growth, IFN- $\alpha$ was observed to downregulate IL-6R expression in these cells in a manner similar to those myeloma cell lines that were growth arrested by IFN- $\alpha$. This observation prompted us to question the functional consequences of IL-6R downregulation. Because we have shown that Stat activation is a rapid and sensitive measure of signaling via the IL-6R in all four of our cell lines, we used this as a measure of IL-6R function after pretreatment with IFN- $\alpha$. Stat protein activation was clearly induced by IL- 6 in all four cell lines, even after a 48-h preincubation with IFN- $\alpha$. However, it is important to acknowledge that higher concentrations of IL-6 were required to result in similar levels of Stat activation in the IFN- $\alpha$ pretreated populations. Because binding of IL-6 does not reach equilibrium for $2 \mathrm{~h}$ and Stat activation was assayed after 20 min of IL- 6 stimulation, the higher concentrations of IL-6 likely shift the kinetics of IL-6 binding to its receptor. Regardless of this caveat, the data clearly show that the IL-6Rs were still fully functional on each of the cell lines as defined by Stat factor activation. Therefore, our data indicate that downregulation of IL-6R expression does not appear to correlate with antiproliferative activity. It is interesting to note that there is a consensus GAS element located $\sim 300 \mathrm{bp}$ upstream of the initiator codon of human gp80. The functionality of this putative element has yet to be tested. Finally, it re- mains possible that IFN- $\alpha$-mediated downregulation of IL-6R expression on myeloma cells results in deficient signaling via other pathways such as the Ras-MAP kinase pathway (for review see reference 49). Currently, we are investigating this possibility as well as the effects of IFN- $\alpha$ on more membraneproximal events (Arora, T., and D.F. Jelinek, manuscript in preparation).

In summary, the results presented in this study further promote the notion of myeloma as a heterogeneous disease and clearly substantiate the work of others that has shown that IFN- $\alpha$ is not uniformly growth inhibitory for myeloma cells. Although our results have excluded differential activation of Stat proteins as a mechanism to account for this heterogeneity, given the complex chromosomal changes that are often present in this disease, it is plausible that differential growth regulation may reflect differences that lie within the set of available IFN-responsive target genes that are accessible in each cell line or in each patient's clonal tumor cell population.

\section{Acknowledgments}

The authors wish to thank Dr. Selina Chen-Kiang for helpful advice regarding analysis of Stat protein activation, Dr. Chris Schindler for providing antibody to Stat 2, Drs. Kim Kalli, David McKean, and Robert Abraham for helpful discussions regarding analysis of IL-6R numbers, and Terri Felmlee for her help in preparing this manuscript.

This work was supported by the Mayo Foundation and National Institutes of Health grants CA62242 and CA62228 (awarded to D.F. Jelinek)

\section{References}

1. Pestka, S., J. Langer, K.C. Zoon, and C. Samuel. 1987. Interferons and their actions. Annu. Rev. Biochem. 56:727-777.

2. Gutterman, J.U. 1994. Cytokine therapeutics: lessons from interferon $\alpha$. Proc. Natl. Acad. Sci. USA. 91:1198-1205.

3. Gresser, I. 1991. Antitumour effects of interferons: past, present and future. Br. J. Haematol. 79:1-5.

4. Mellstedt, H., A. Ahre, M. Bjorkholm, G. Holm, B. Johansson, and H. Strander. 1979. Interferon therapy in myelomatosis. Lancet. 1:245-247.

5. Oken, M.M. 1994. Standard treatment of multiple myeloma. Mayo Clin. Proc. 69:781-786.

6. Browman, G.P., D. Bergsagel, D. Sicheri, S. O'Reilly, K.S. Wilson, S. Rubin, A. Belch, C. Shustik, R. Barr, I. Walker, et al. 1995. Randomized trial of interferon maintenance in multiple myeloma: a study of the National Cancer Institute of Canada clinical trials group. J. Clin. Oncol. 13:2354-2360.

7. Ludwig, H., A.M. Cohen, A. Polliack, H. Huber, D. Nachbaur, H.-J. Senn, R. Morant, S. Eckhardt, P. Günczler, H.L. Seewann, et al. 1995. Interferon-alpha for induction and maintenance in multiple myeloma: results of two multicenter randomized trials and summary of other studies. Ann. Oncol. 6: 467-476.

8. Bladé, J., A. López-Guillermo, D. Tassies, E. Montserrat, and C. Rozman. 1991. Development of aggressive plasma cell leukaemia under interferon-alpha therapy. Br. J. Haematol. 79:523-525.

9. Sawamura, M., K. Murayama, G. Ui, T. Matsushima, J. Tamura, H. Murakami, T. Naruse, and J. Tsuchiya. 1992. Plasma cell leukaemia with alphainterferon therapy in myeloma. Br. J. Haematol. 82:631.

10. Brenning, G. 1985. The in vitro effect of leucocyte $\alpha$-interferon on human myeloma cells in a semisolid agar culture system. Scand. J. Haematol. 35: $178-185$.

11. Brenning, G., A. Ahre, and K. Nilsson. 1985. Correlation between in vitro and in vivo sensitivity to human leucocyte interferon in patients with multiple myeloma. Scand. J. Haematol. 35:543-549.

12. Jourdan, M., X.G. Zhang, M. Portier, J.-M. Boiron, R. Bataille, and B. Klein. 1991. IFN- $\alpha$ induces autocrine production of IL-6 in myeloma cell lines. J. Immunol. 147:4402-4407.

13. Brenning, G., H. Jernberg, M. Gidlund, O. Sjöberg, and K. Nilsson. 1986. The effect of $\alpha$ and $\gamma$-interferon on proliferation and production of $\operatorname{IgE}$ and $\beta_{2}$-microglobulin in the human myeloma cell line U-266 and in an $\alpha$-interferon resistant U-266 subline. Scand. J. Haematol. 37:280-288.

14. Einhorn, S., J.-O. Fernberg, D. Grandér, and R. Lewensohn. 1988. Interferon exerts a cytotoxic effect on primary human myeloma cells. Eur. J. Cancer Clin. Oncol. 24:1505-1510. 
15. Schwabe, M., A.T. Brini, M.C. Bosco, F. Rubboli, M. Egawa, J. Zhao, G.L. Princler, and H. Kung. 1994. Disruption by interferon- $\alpha$ of an autocrine interleukin 6 growth loop in IL-6-dependent U266 myeloma cells by homologous and heterologous downregulation of the IL-6 receptor $\alpha$ and $\beta$ chains. J. Clin. Invest. 94:2317-2325.

16. Anthes, J.C., Z. Zhan, H. Gilchrest, R.W. Egan, M.I. Siegel, and M.M Billah. 1995. Interferon- $\alpha$ down-regulates the interleukin-6 receptor in a human multiple myeloma cell line, U266. Biochem. J. 309:175-180.

17. Kawano, M., T. Hirano, T. Matsuda, T. Taga, Y. Horii, K. Iwato, B. Tang, O. Tanabe, H. Tanaka, A. Kuramoto, and T. Kishimoto. 1988. Autocrine generation and requirement of BSF-2/IL6 for human multiple myeloma. Nature (Lond.). 332:83-85.

18. Palumbo, A., S. Battaglio, P. Napoli, P. Omedè, A. Fusaro, B. Bruno, M. Boccadoro, and A. Pileri. 1994. Recombinant interferon- $\gamma$ inhibits the in vitro proliferation of human myeloma cells. Br. J. Haematol. 86:726-732.

19. Portier, M., X.-G. Zhang, E. Caron, Z.-Y. Lu, R. Bataille, and B. Klein. 1993. $\gamma$-Interferon in multiple myeloma: inhibition of interleukin-6 (IL-6)dependent myeloma cell growth and downregulation of IL-6-receptor expression in vitro. Blood. 81:3076-3082.

20. Ihle, J.N. 1995. The Janus protein tyrosine kinase family and its role in cytokine signaling. Adv. Immunol. 60:1-35.

21. Schindler, C., and J.E. Darnell, Jr. 1995. Transcriptional responses to polypeptide ligands: the JAK/STAT pathway. Annu. Rev. Biochem. 64:621-651.

22. Harroch, S., M. Revel, and J. Chebath. 1994. Induction by interleukin-6 of interferon regulatory factor 1 (IRF-1) gene expression through the palindromic interferon response element pIRE and cell type-dependent control of IRF-1 binding to DNA. EMBO (Eur. Mol. Biol. Organ.) J. 13:1942-1949.

23. Harroch, S., Y. Gothelf, N. Watanabe, M. Revel, and J. Chebath. 1993. Interleukin-6 activates and regulates transcription factors of the interferon regulatory factor family in M1 cells. J. Biol. Chem. 268:9092-9097.

24. Taniguchi, T., H. Harada, and M. Lamphier. 1995. Regulation of the interferon system and cell growth by the IRF transcription factors. J. Cancer Res. Clin. Oncol. 121:516-520.

25. Tanaka, N., M. Ishihara, M. Kitagawa, H. Harada, T. Kimura, T. Matsuyama, M.S. Lamphier, S. Aizawa, T.W. Mak, and T. Taniguchi. 1994. Cellular commitment to oncogene-induced transformation or apoptosis is dependent on the transcription factor IRF-1. Cell. 77:829-839.

26. Minami, M., M. Inoue, S. Wei, K. Takeda, M. Matsumoto, T. Kishimoto, and S. Akira. 1996. STAT3 activation is a critical step in gp130-mediated terminal differentiation and growth arrest of a myeloid cell line. Proc. Natl. Acad. Sci. USA. 93:3963-3966.

27. Yamanaka, Y., K. Nakajima, T. Fukada, M. Hibi, and T. Hirano. 1996. Differentiation and growth arrest signals are generated through the cytoplasmic region of gp130 that is essential for Stat3 activation. EMBO (Eur. Mol. Biol. Organ.) J. 15:1557-1565.

28. Yang, C.-H., W. Shi, L. Basu, A. Murti, S.N. Constantinescu, L. Blatt, E. Croze, J.E. Mullersman, and L.M. Pfeffer. 1996. Direct association of STAT3 with the IFNAR-1 chain of the human type I interferon receptor. J. Biol. Chem. 271:8057-8061.

29. Chin, Y.E., M. Kitagawa, W.-C.S. Su, Z.-H. You, Y. Iwamoto, and X.-Y. Fu. 1996. Cell growth arrest and induction of cyclin-dependent kinase inhibitor $\mathrm{p} 21^{\mathrm{WAF} 1 / \mathrm{CIP} 1}$ mediated by STAT1. Science (Wash. DC). 272:719-722.

30. Jelinek, D.F., G.J. Ahmann, P.R. Greipp, S.M. Jalal, J.J. Westendorf, J.A. Katzmann, R.A. Kyle, and J.A. Lust. 1993. Coexistence of aneuploid subclones within a myeloma cell line that exhibits clonal immunoglobulin gene rearrangement: clinical implications. Cancer Res. 53:5320-5327.

31. Westendorf, J.J., G.J. Ahmann, P.R. Greipp, T.E. Witzig, R.A. Kyle, J.A. Lust, and D.F. Jelinek. 1996. Establishment and characterization of three myeloma cell lines that demonstrate variable cytokine responses and abilities to produce autocrine interleukin-6. Leukemia. 10:866-876.

32. Wagner, B.J., T.E. Hughes, C.J. Hogan, and B.H. Cochran. 1990. The SIF binding element confers sis/PDGF inducibility onto the c-fos promoter. EMBO (Eur. Mol. Biol. Organ.) J. 9:4477-4484.

33. Ali Imam, A.M., A.M. Ackrill, T.C. Dale, I.M. Kerr, and G.R. Stark 1990. Transcription factors induced by interferons $\alpha$ and $\gamma$. Nucleic Acids Res. 18:6573-6580

34. Gao, P.-Q., S.H. Sims, D.C. Chang, and A.B. Deisseroth. 1993. Interferon- $\gamma$ priming effects in the activation and deactivation of ISGF3 in K562 cells. J. Biol. Chem. 268:12380-12387.

35. Sadowski, H.B., K. Shuai, J.E. Darnell, Jr., and M.Z. Gilman. 1993. A common nuclear signal transduction pathway activated by growth factor and cytokine receptors. Science (Wash. DC). 261:1739-1744.

36. Zhang, X., J. Blenis, H.-C. Li, C. Schindler, and S. Chen-Kiang. 1995. Requirement of serine phosphorylation for formation of STAT-promoter complexes. Science (Wash. DC). 267:1990-1994.

37. Williams, B.R.G. 1991. Transcriptional regulation of interferon-stimulated genes. Eur. J. Biochem. 200:1-11.

38. Tanaka, N., and T. Taniguchi. 1992. Cytokine gene regulation: regulatory cis-elements and DNA binding factors involved in the interferon system. Adv. Immunol. 52:263-281.

39. Williams, B.R.G., and I.M. Kerr. 1980. The 2-5A system in interferontreated and control cells. Trends Biochem. Sci. 5:138-140.

40. Heslop, H.E., A.C.M. Bianchi, F.T. Cordingley, M. Truner, W.C.P. De Mel, A.V. Hoffbrand, and M.K. Brenner. 1990. Effects of interferon $\alpha$ on autocrine growth factor loops in B lymphoproliferative disorders. J. Exp. Med. 172: 1729-1734.

41. Westendorf, J.J., G.J. Ahmann, R.J. Armitage, M.K. Spriggs, J.A. Lust, P.R. Greipp, J.A. Katzmann, and D.F. Jelinek. 1994. CD40 expression in malignant plasma cells: role in stimulation of autocrine IL-6 secretion by a human myeloma cell line. J. Immunol. 152:117-128.

42. Yamada, G., M. Ogawa, K. Akagi, H. Miyamoto, N. Nakano, S. Itoh, J.-I. Miyazaki, S.-I. Nishikawa, K.-I. Yamamura, and T. Taniguchi. 1991. Specific depletion of the B-cell population induced by aberrant expression of human interferon regulatory factor 1 gene in transgenic mice. Proc. Natl. Acad. Sci. USA. 88:532-536.

43. Harada, H., M. Kitagawa, N. Tanaka, H. Yamamoto, K. Harada, M. Ishihara, and T. Taniguchi. 1993. Anti-oncogenic and oncogenic potentials of interferon regulatory factors-1 and -2. Science (Wash. DC). 259:971-974.

44. Friedman, R.L., S.P. Manly, M. McMahon, I.M. Kerr, and G.R. Stark. 1984. Transcriptional and post-transcriptional regulation of interferon-induced gene expression in human cells. Cell. 38:745-755.

45. Larner, A.C., A. Chaudhuri, and J.E. Darnell, Jr. 1986. Transcriptional induction by interferon. J. Biol. Chem. 261:453-459.

46. Harvey, W.H., O.S. Harb, S.T. Kosak, J.C. Sheaffer, L.R. Lowe, and N.A. Heerema. 1994. Interferon-alpha-2b downregulation of oncogenes H-ras, c-raf-2, c-kit, c-myc, c-myb and c-fos in eskol, a hairy cell leukemic line, results in temporal perturbation of signal transduction cascade. Leukemia Res. 18:577585

47. McKean, D.J., R. Podzorski, M. Bell, A. Nilson, C. Huntoon, J. Slack, S Dower, and J.E. Sims. 1993. Murine $\mathrm{T}_{\mathrm{H}} 2$ lymphocytes express type I and type II IL-1 receptors, but only the type I receptor mediates costimulatory activity. $J$. Immunol. 151:3500-3510.

48. Sims, J.E., M.A. Gayle, J.L. Slack, M.R. Alderson, T.A. Bird, J.D. Giri, F. Colotta, F. Re, A. Mantovani, K. Shanebeck, et al. 1993. Interleukin 1 signaling occurs extensively via the type I receptor. Proc. Natl. Acad. Sci. USA. 90: $6155-6159$.

49. Kishimoto, T., S. Akira, M. Narazaki, and T. Taga. 1995. Interleukin-6 family of cytokines and gp130. Blood. 86:1243-1254. 